JEL Classification: M41, D29, M11

\title{
ПРО УДОСКОНАЛЕННЯ ПЛАНУ РАХУНКІВ БУХГАЛТЕРСЬКОГО ОБЛІКУ ДЛЯ ЦІЛЙ УПРАВЛІННЯ
}

\author{
Ковальова Т.В. канд. екон. наук, доцент \\ Харківський національний автомобільно-дорожній університет
}

Постановка проблеми. Ефективність управлінських рішень в значній мірі залежить від своєчасного отримання інформації про здійснювані господарські операції. Основним джерелом такої інформації є бухгалтерський облік, важливим елементом метода якого $є$ рахунки. Вони призначені для відображення, реєстрації та групування фактів фінансового-господарської діяльності підприємства. Саме тому вагомого значення набуває чітка та раціональна побудова Плану рахунків. Рахунки бухгалтерського обліку, якщо їх правильно упорядкувати, і забезпечать управлінців інформацією для вирішення багатьох завдань. Однак, таких рахунків у діючому в нашій країні Плані рахунків, запропоновано не було, що і привело до певних труднощів серед управлінців щодо прийняття певних рішень.

Аналіз останніх досліджень і публікацій. В Україні проблемам управлінської орієнтації бухгалтерського обліку присвячені роботи С.Ф.Голова [1], М.С.Пушкаря [2], В.В.Сопка [3], Н.В. Осадчук [4], та інших вчених. Про використання елементів методу бухгалтерського обліку для цілей управління вели мову у своїх роботах С.Ф.Голов, Н.В. Осадчук, Л.В. Нападовська [5], Ю.О.Волкова [6], та ін.. Усі ці автори, у тій чи іншій мірі розглядали питання пов'язані з реформуванням Плану рахунків для цілей оперативного управління, у той же час, деякі наукові точки зору щодо цього питання не знайшли широкої підтримки і не були взяті за основу, як методологічні. А отже потребують подальшого вивчення. 
Невирішені складові загальної проблеми. Перші публікації науковців щодо необхідності реформування Плану рахунків 3'явились майже зразу після введення його в дію. Однак, до сьогоднішнього дня ця проблема не вирішена i не втратила своєї актуальності. Сучасні публікації науковців висвітлюють напрями розвитку та реформування бухгалтерського обліку, його складових, в контексті адаптації до вимог вітчизняної економіки, міжнародних глобалізаційних процесів, динамічно змінюваного внутрішнього й зовнішнього середовища підприємств. Досвід наукової розробки теорії і методології бухгалтерського обліку, накопичений зарубіжний i вітчизняний досвід обумовлюють необхідність узагальнення та систематизації наукових поглядів щодо концептуальних засад та перспектив розвитку обліку, складових його методу, в контексті ефективного управління підприємством.

Формулювання цілей статі. Метою даного дослідження $\epsilon$ удосконалення Плану рахунків бухгалтерського обліку для цілей оперативного управління підприємством

Виклад основного матеріалу дослідження. План рахунків - це частина облікової діяльності, що підлягає найбільшим змінам при введенні інтегрованої системи обліку. Це пов'язане з тим, що інтегрована система обліку - це синтез управлінського й фінансового обліку 3 метою ефективності, зручності й економічності ведення обліку на підприємствах, що спричиняє зміни в методах керування, організації виробництва, у фінансово-кредитній системі й т.п. $Є$ кілька основних підходів до побудови структури плану рахунків: двоколовий (автономний) та інтегрований (моністичний). У першому випадку виділяють два кола обліку: фінансовий та управлінський. Цей принцип бере свій початок у книгах Г. Готтшалька (1815 р.), класичний варіант - Франція. Він реалізований у більш ніж 80 країнах світу [7], у тому числі, у більшості країн Свросоюзу. Сутність його полягає в тому, що утворюються дві автономні системи рахунків, одна для фінансового - інша для управлінського обліку, які не кореспондують між собою. Інтегрований принцип зазвичай функціонує без окремого управлінського плану рахунків: використається єдина система 
рахунків фінансового обліку та бухгалтерських проводок, у якій додаються й відкриваються спеціальні субрахунку другого й третього порядку. Для цілей управлінського обліку інформацію фінансового обліку накопичують у спеціальних регістрах, доповнюючи “ï своїми даними й результатами розрахунку.

Для того, щоб визначитись зі змінами у Плані рахунків нашої країни ми звернулись за досвідом до зарубіжних країн. Нині створено три міжнародні плани рахунків бухгалтерського обліку: Європейського Союзу; Африканського Союзу; Англосаксонської облікової системи. Побудова Плану рахунків бухгалтерського обліку України, особливо виділення 9 класу рахунків «Витрати діяльності», показує, що в Україні передбачено використання інтегрованого принципу ведення управлінського обліку [8]. План рахунків України тісно пов'язаний із структурою балансу та звіту про фінансові результати. Так, залишки на рахунках класів $1-3$ є підставою для складання активу балансу, класів 4-6 - пасиву балансу. А рахунки класів 7-9 побудовано з огляду на потребу підготовки звіту про фінансові результати. Дані рахунків класу 0 забезпечують інформацію, необхідну для заповнення приміток до фінансових звітів. Таким чином, Планом рахунків передбачене відображення облікової інформації відповідно до вимог звітності, що значно полегшує та прискорює іiі складання. Під час його розробки використовувались загальновживані принципи бухгалтерського обліку і фінансової звітності, основні положення Закону «Про бухгалтерський облік і фінансову звітність в Україні», міжнародні та національні стандарти бухгалтерського обліку. У практиці закордонного обліку найпоширенішим підходом до класифікації бухгалтерських рахунків $€$ класифікація в розрізі п'яти елементів, що становлять фінансову звітність: активи, зобов'язання, капітал, доходи, витрати. Європейська комісія склала й прийняла ряд директив, обов'язкових для виконання всіма учасниками Європейського союзу. Реалізація їх дає можливість удосконалювати, гармонізувати інтегровану систему обліку. Для характеристики плану рахунків ЄС використається план рахунків Франції, як найбільш розповсюджений 
(типовий). Порівнюючи плани рахунків більшості країн СС та України, слід відзначити, що наша країна застосовує ту ж десяткову систему. Тобто, 1 номер класу, 2 - номер рахунку в класі (синтетичний), 3 - субрахунок першого порядку, 4,5 - субрахунки другого й третього порядку для цілей управлінського обліку, 6 - аналітичні рахунки. Така система дозволяє вести економічний, зручний управлінський і фінансовий облік у рамках єдиного плану рахунків [9].

Особливістю плану рахунків Африканського Союзу є чітке визначення класів рахунків у двох розділах: перший розділ - рахунки фінансової бухгалтерії, другий - рахунки управлінської бухгалтерії. Характерною ознакою Англосаксонської облікової системи $\epsilon$ відсутність загальноприйнятих національних планів рахунків (Великобританія, США, Канада). Аналіз закордонної практики побудови планів рахунків дозволив зробити висновок, що плани рахунків у різних частинах світу відрізняються один від одного, однак, вони дозволяють формувати економічну інформацію високої інформаційної ємності, і бути «гнучким» для здійснення бухгалтерського керування економічними процесами. Проблеми методологічного характеру пов'язані з необхідністю ухвалити рішення, щодо внесення змін у існуючий План рахунків нашої країни, шляхом включення до нього розділу (класу) рахунків управлінського обліку за аналогом рахунків аналітичної експлуатації. Це дозволить враховуючи закордонний досвід країн $\mathrm{\epsilon C}$, забезпечити порівнянність агрегованих даних на всіх рівнях управління. Н.В.Осадчук у своїх дослідженнях запропонувала розвиток українського Плану рахунків бухгалтерського обліку шляхом введення в нього розділу «Рахунки управлінської бухгалтерії» [4]. План рахунків бухгалтерського обліку активів, капіталу, зобов'язань і господарських операцій підприємств і організацій [10] враховує вимоги ринкової економіки та будується на загальносвітовій практиці та принципах побудови планів бухгалтерських рахунків [11]: точне відображення майнового та фінансового стану підприємства, оцінка коштів та ïх джерел, обачність, виокремлення бухгалтерських періодів, сталість використовуваних методів, доброякісність інформації та продовження 
діяльності; чітке виділення в плані рахунків таких категорій, як: балансові рахунки (активні, пасивні, активно-пасивні). В цю групу, як правило, входить п’ять класів рахунків, які дозволяють скласти бухгалтерський баланс; рахунки «витрати-випуск», призначені для визначення результату в цілому по підприємству за видами діяльності: звичайна, операційна, інвестиційна, фінансова, інша. В цю групу в залежності від облікової системи входять дватри класи рахунків; виділення основних рахунків, субрахунків першого та другого порядку, при цьому рахунки розрізняються за допомогою кодування за десятковою системою, що необхідно для автоматизації облікових процесів та вирішення управлінських проблем [4]. Далі Н.В.Осадчук вказує на недосконалість діючого Плану рахунків щодо управлінської частини, зокрема вона вказує на відсутність: рахунків управлінської, маржинальної, аналітичної, допоміжної бухгалтерії, які використовуються для прийняття оперативних управлінських рішень, визначення і аналізу собівартості, результатів діяльності підприємства в розрізі центрів відповідальності. В залежності від облікової системи ця група може містити один-три класи рахунків; рахунків, які забезпечують зв’язок між фінансовою та управлінською бухгалтеріями [4].

Запровадження нового Плану бухгалтерських рахунків у 2000 р., відбувалось з урахуванням необхідності адаптаційного періоду для освоєння на підприємствах як нової логіки бухгалтерського обліку, так і Плану рахунків. Тому, введення в 2000 р. в план рахунків ще й рахунків управлінської бухгалтерії було б недоцільно. Уніфікованого класу рахунків управлінського обліку в Плані бухгалтерських рахунків вітчизняним підприємствам запропоновано не було, тому кожне 3 них формувало такі рахунки для себе самостійно без будь-якого методологічного підгрунтя. Ми пропонуємо звернутися за досвідом до Європейських країн, зокрема, Франції, де при використанні рахунків 9-го класу Загального плану рахунків в бухгалтерському обліку забезпечується їх автономне функціонування, а також складання в кінці звітного періоду рахунку «Фінансові результати поточної діяльності» шляхом списання на його сальдо доходів та витрат. Здійснювані на протязі звітного 
періоду господарські операції на підприємстві класифікуються по двох категоріях: які не мають ніяких наслідків для результатів звітного періоду; ті, які їх викликають. До першої категорії відносяться інвестиції, розрахунки між кредиторами та дебіторами, позики та займи. Друга категорія складається 3 придбання товарів та матеріалів, поточних видатків, необхідних для забезпечення регулярної діяльності підприємства, та продажів, включаючи надані послуги та виконані роботи. Рахунки 9-го класу Загального плану рахунків Франції формують комплекс технічних можливостей для організації аналітичної, управлінської та стратегічної бухгалтерії [4]. В.А. Москаленко пропонує для ефективного ведення обліку використовувати раніше прийняту на підприємстві систему рахунків бухгалтерського обліку, але на певному етапі процесу обліку виділяти окрему, автономну гілку. Тобто всі матеріальні, розрахункові, затратні та інші рахунки будуть загальними як для управлінського, так і для фінансового обліку, а окрема гілка починається 323 рахунку «Виробництво». Дебет рахунку в управлінському обліку буде співпадати з дебетом рахунку в фінансовому обліку, а от по кредиту готову продукцію будемо обліковувати по бюджетній собівартості, а не по справедливій вартості, як це робиться у фінансовому обліку. Замикати таку автономну гілку управлінського обліку буде рахунок, який називається «Прибутки та збитки (калькуляційний рахунок)». Крім названих рахунків необхідно додатково відкрити лише два рахунки: «Готова продукція по плановій собівартості» та «Собівартість реалізованої продукції»[12]. Така точка зору, безумовно, є досить цікавою, але, на наш погляд, бухгалтеру буде складно одночасно здійснювати цей облік, і потом, гілка, як вона буде виражена в робочому плані рахунків, як окремі субрахунки? Ця теорія підлягає, на наш погляд, доопрацюванню. Лебедик Г.В., Іващенко К.Ю., Світловської А.М., рекомендують, для того щоб система управлінського обліку вбудувалася в існуючу облікову систему, необхідно створити синтетичні облікові класифікатори та кодифікатори, що включають у себе кодування як бухгалтерського обліку, так і управлінського. При цьому рахунки витрат 
групуються і розбиваються за необхідними для обраного методу обліку аналітичними показниками. Основою для створення синтетичних рахунків повинне стати існуюче кодування бухгалтерського обліку або рахунків за МСФ3 (податкового обліку). При створенні Робочого плану рахунків усі бухгалтерські проводки за господарськими операціями приводяться до одного або кількох типових зразків [13]. Н.В. Осадчук вважає, що у зв’язку з тим, що в українському Плані бухгалтерських рахунків всі класи рахунків з 0 по 9 вже зайняті, а діалектика економічного життя кожного підприємства вимагає від обліку можливості отримання інформації для оперативного управління саме із застосуванням бухгалтерських рахунків, доцільно було б об'єднати всі наявні класи бухгалтерських рахунків в перший розділ «Рахунки фінансової бухгалтерії», і ввести другий Розділ «Рахунки управлінської бухгалтерії» [4]. Ми вважаємо за доцільне не змінювати назви розділів, а доповнити до існуючого розділу «Позабалансові рахунки» ще один клас - 01 «Рахунки управлінського обліку». Ця назва класу була більш звичною для наших фахівців і вона наочно відображає орієнтацію на задоволення потреб оперативного управління, оптимізацію використання ресурсів, забезпечення об'єктивної оцінки діяльності підрозділів і окремих менеджерів. Тобто, бухгалтерська служба стає безпосередньо учасником прийняття тактичних i стратегічних рішень, визначення й аналізу собівартості продукції і приймає активну участь у збільшенні прибутку. Наповнення 01 класу відповідними рахунками буде залежати від ряду факторів, зокрема, методу обліку витрат. Тому, на підприємстві слід розробити Робочий план рахунків. Ми поділяємо точку зору Лебедик Г.В., Іващенко К.Ю., Світловської А.М., які вказали на наступне: «Створивши Робочий план рахунків, варто розробити для дієздатності системи управлінського обліку такі документи: Положення про облікову політику та фінансову структуру підприємства; Робочий план рахунків, єдині класифікатори і кодифікатори управлінського обліку та інструкції із застосування; форми звітних документів для управлінського обліку; наказ про призначення відповідальних працівників за формування i 
ведення регістрів управлінського обліку та цільових програм за напрямками діяльності підприємства. Усі документи повинні бути взаємопов’язані, а домінуючим документом $€$ Положення про облікову політику» [13]. Запровадження додаткового класу у Плані рахунків дасть змогу забезпечити формування інформації для складання внутрішніх i зовнішніх звітів, які необхідні для управління підприємством.

Висновки 3 проведеного дослідження. Таким чином, дослідження структури плану рахунків Україні, в контексті відображення в ньому аспектів управлінського обліку, дало нам можливість зробити висновок про необхідність ухвалити рішення, щодо внесення змін у існуючий План рахунків нашої країни, шляхом включення до нього розділу (класу) рахунків управлінського обліку за аналогом рахунків аналітичної експлуатації. Це дозволить враховуючи закордонний досвід країн $\mathrm{CC}$, забезпечити порівнянність агрегованих даних на всіх рівнях управління. Упровадження в український План бухгалтерських рахунків нових рахунків 3 управлінського обліку є одним 3 найактуальніших шляхів його розвитку, а з іншого боку, уніфікація рахунків управлінського обліку в масштабах всієї країни потребує подальшої і досить грунтовної методологічної та методичної роботи.

\section{Перелік посилань}

1. Голов С. Ф. Бухгалтерський облік в Україні: аналіз стану та перспективи розвитку: монографія. Київ, 2007. 522 с.

2. Пушкар М. С. Тенденції та закономірності розвитку бухгалтерського обліку в Україні (теоретико - методологічні аспекти): монографія. Тернопіль, 1999. 422 c.

3. Сопко В. В. Бухгалтерський облік - базовий інструмент державної регулювальної політики забезпечення фінансово-економічної стабільності та економічного розвитку. Наукові записки НаУКМА. Економічні науки. 2012. Т. 133. C. 115-125.

4. Осадчук Н. В. Розвиток українського плану рахунків бухгалтерського обліку для завдань оперативного управління підприємством: сайт. URL: 
http://www.pratsi.opu.ua/app/webroot/articles/1312893893.pdf (дата звернення: 15.01.2019).

5. Нападовська Л. В. Управлінський облік: монографія. Дніпропетровськ: Наука і освіта, 2000. 450 с.

6. Волкова О. Ю. Елементи методу управлінського обліку. Всеукраїнські наукові економічні читання з міжнародною участю Заможне суспільство, конкурентоспроможна економіка, ефективна держава: шляхи та засоби побудови: сайт. URL:conference.nuos.edu.uа (дата звернення: 15.01.2019)

7. Соколов Я. В., Бутинец Ф. Ф., Горецкая Л. Л., Панкив Д. А. Бухгалтерський учет в зарубежных странах: Ученик. Москва, 2005. 664 с.

8. Партин Г. О., Загородній А. Г., Свідрик Т. І., Ясінська А. І., Бойчук Т. М. Управлінський облік: підручник. Львів, 2013. 280 с.

9. Широбокова В. Г. Французький досвід організації обліку господарської діяльності сільськогосподарських організацій. Міжнародний бухгалтерський облік. 2007. № 2. С. 17-21.

10. План рахунків бухгалтерського обліку активів, капіталу, зобов'язань і господарських операцій підприємств і організацій. Затв. наказом Мінфіну України від 30.11.99 p. № 291: сайт. URL: http://zakon4.rada.gov.ua/laws/show/z0893-99 (дата звернення: 17.01.2019).

11. Libby R., Short D. Financial accounting. New York: Von Hoffmann Press, Inc., $1998.815 \mathrm{p}$.

12. Москаленко В. А. Впровадження управлінського обліку в підприємствах агропромислового комплексу: сайт. URL: file:///C:/Users/User/Downloads/efek_2013_5_35\%20(2).pdf (дата звернення: 17.01.2019)

13. Лебедик Г. В., Іващенко К. Ю., Світловська А. М. Проблеми організації управлінського обліку на підприємствах: сайт. URL: http://www.vestnik-econom.mgu.od.ua/journal/2016/15-2016/31.pdf ～(дата звернення: 30.01.2019). 


\section{References}

1. Golov, S. F. (2007), Accounting area in Ukraine: analysis of the future and prospects of development: monograph [Bukhhalterskyi oblik v Ukraini: analiz stanu ta perspektyvy rozvytku: monohrafiia], Kiev, 522 p.

2. Pushkar, M. S. (1999), Tendencies and laws of the accounting area in Ukraine (theoretical - methodological aspects): monograph [Tendentsii ta zakonomirnosti rozvytku bukhhalterskoho obliku v Ukraini (teoretyko metodolohichni aspekty): monohrafiia], Ternopil, 422 p.

3. Sopko, V. V. (2012), «Accounting region - the basic instrument of the state regulatory policy of security policy financial and economic stability and economic development» [«Bukhhalterskyi oblik - bazovyi instrument derzhavnoi rehuliuvalnoi polityky zabezpechennia finansovo-ekonomichnoi stabilnosti ta ekonomichnoho rozvytku»], Naukovi notes NaUKMA. Economical science, T. 133, P. 115-125.

4. Osadchuk, N. V. The development of the Ukrainian plan for the accounting area for the operational management of the company [Rozvytok ukrainskoho planu rakhunkiv bukhhalterskoho obliku dlia zavdan operatyvnoho upravlinnia pidpryiemstvom], available at http://www.pratsi.opu.ua/app/webroot/articles/1312893893.pdf (last accessed:. 15.01.2019).

5. Napadovska, L. V. (2000), Management area: monograph [Upravlinskyi oblik: monohrafiia], Dnipropetrovsk: Science and Studies, $450 \mathrm{p}$.

6. Volkova, O. Yu. Elementy method management region. Ukrainian National Economic Forum Reading the International Participation Replace the organization, competing economics, effective power: nobility and promise [Elementy metodu upravlinskoho obliku. Vseukrainski naukovi ekonomichni chytannia z mizhnarodnoiu uchastiu Zamozhne suspilstvo, konkurentospromozhna ekonomika, efektyvna derzhava: shliakhy ta zasoby pobudovy], available at: conference.nuos.edu.ua (last accessed: 15. 01.2019) 
7. Sokolov, Ya. V., Butinets, F. F., Goretskaya, L. L., Pankiv, D. A. (2005), Accounting in foreign countries [Bukhgalters'kiy uchet $v$ zarubezhnykh stranakh], Student, Moscow, 664 p.

8. Partin, G. O. , Zagorodniy, A. G. , Svidrik, T.I., Yasinska, A. I., Boychuk, T. M. (2013), Management region: pidruchnik [Upravlinskyi oblik: pidruchnyk], Lviv, 280 p.

9. Shirobokova, V. G. (2007), «French dosvid organizatsiï region of gospodarskoi diyalnost silskogospospodarskikh organizizatsiy» [«Frantsuzkyi dosvid orhanizatsii obliku hospodarskoi diialnosti silskohospodarskykh orhanizatsii»], International Accounting Region, No. 2, P. 17-21.

10. Plan rahunkiv accounting area active, capital, goiter and government operations of the organization. Sat. Order of the Ministry of Finance of Ukraine vid 30.11.99 p. Number 29 [Plan rakhunkiv bukhhalterskoho obliku aktyviv, kapitalu, zoboviazan i hospodarskykh operatsii pidpryiemstv i orhanizatsii. Zatv. nakazom Minfinu Ukrainy vid 30.11.99 r. No. 291], available at: http://zakon4.rada.gov.ua/laws/show/z0893-99 (last accessed: 17.01.2019).

11. Libby, R., Short, D. (1998), Financial accounting. New York: Von Hoffmann Press, Inc., 815 p.

12. Moskalenko, V. A. In the Direction of the Administrative Region in the Companies of the Agro-Industrial Complex [Vprovadzhennia upravlinskoho obliku v pidpryiemstvakh ahropromyslovoho kompleksu], available at: file: /// C: / Users / User / Downloads / efek_2013_5_35\% 20 (2) .pdf (last accessed: 17. 01.2019)

13. Lebedik G.V., Ivashchenko K.Yu., Svitlovska A.M. Problems of Organizational Management in the Company [Problemy orhanizatsii upravlinskoho obliku na pidpryiemstvakh], available at: http://www.vestnikeconom.mgu.od.ua/journal/2016/15-2016/31.pdf (last accessed: 30.01.2019). 


\section{РЕФЕРАТИ / РЕФЕРАТЫ / ABSTRACTS}

\section{УДК 657.4; JEL Classification: M41, D29, M11}

\section{КОВАЛЬОВА Т.В. ПРО УДОСКОНАЛЕННЯ ПЛАНУ РАХУНКІВ БУХГАЛТЕРСЬКОГО ОБЛІКУ ДЛЯ ЦІЛЕЙ УПРАВЛІННЯ}

Метою даного дослідження $\epsilon$ удосконалення Плану рахунків бухгалтерського обліку для цілей оперативного управління підприємством. Методика дослідження: для досягнення поставленої мети у роботі були використані наступні загальнонаукові i спеціальні методи i прийоми дослідження: теоретичного узагальнення, аналізу і синтезу; системного i комплексного підходу; монографічний; абстрактно-логічний. Результати дослідження: результатом наукової роботи $\epsilon$ теоретичне узагальнення i розробка шляхів удосконалення Плану рахунків бухгалтерського обліку активів, капіталу, зобов'язань і господарських операцій підприємств і організацій щодо цілей оперативного управління підприємством. Інформація $\epsilon$ невичерпним та завжди актуальним ресурсом. Дослідження структури плану рахунків Україні, в контексті відображення в ньому аспектів фінансового й управлінського обліку, дало нам можливість зробити висновок про необхідність ухвалити рішення, щодо внесення змін у існуючий План рахунків нашої країни, шляхом включення до нього розділу (класу) рахунків управлінського обліку за аналогом рахунків аналітичної експлуатації. Це дозволить враховуючи закордонний досвід країн $\mathrm{CC}$, забезпечити порівнянність агрегованих даних на всіх рівнях управління. Упровадження в український План бухгалтерських рахунків нових рахунків з управлінського обліку є одним 3 найактуальніших шляхів його розвитку, а 3 іншого боку, уніфікація рахунків управлінського обліку в масштабах всієї країни потребує подальшої і досить грунтовної методологічної та методичної роботи. Наукова новизна: полягає в комплексному дослідженні Плану рахунків бухгалтерського обліку та розробці рекомендацій щодо вдосконалення існуючого Плану рахунків як елементу управління та інформаційного джерела прийняття рішень. Підходи до побудови Плану рахунків бухгалтерського обліку активів, капіталу, зобов'язань і господарських операцій підприємств i організацій України в частині запропонованого змістовного наповнення новим розділом (класом) дозволить посилити інформативність даного документа та забезпечити порівнянність даних про результати господарської діяльності підприємств у сучасних умовах. Практична значущість: внесення змін до діючого Плану рахунків дасть можливість бухгалтерам 3 управлінського обліку та менеджерам підвищити ефективність діяльності підприємства.

Ключові слова: план рахунків; управління підприємством; управлінський облік; інформація; облік.

УДК 657.4; JEL Classification: M41, D29, M11

КОВАЛЕВА Т.В. ОБ УСОВЕРШЕНСТВОВАНИИ ПЛАНА СЧЕТОВ БУХГАЛТЕРСКОГО УЧЕТА ДЛЯ ЦЕЛЕЙ УПРАВЛЕНИЯ 
Целью данного исследования является усовершенствование Плана счетов бухгалтерского учета для целей оперативного управления предприятием. Методика исследования: для достижения поставленной цели в работе были использованные следующие общенаучные и специальные методы и приемы исследования: теоретического обобщения, анализа и синтеза; системного и комплексного подхода; монографический; абстрактно-логический. Результаты исследования: результатом научной работы является теоретическое обобщение и разработка путей усовершенствования Плана счетов бухгалтерского учета активов, капитала, обязательств и хозяйственных операций предприятий и организаций относительно целей оперативного управления предприятием. Информация это неисчерпаемый и всегда актуальный ресурс. Исследование структуры плана счетов Украине, в контексте отображения в нем аспектов финансового и управленческого учета, дало нам возможность сделать вывод о необходимости утвердить решение, относительно внесения изменений в существующий План счетов нашей страны, путем включения в него раздела (класса) счетов управленческого учета за аналогом счетов аналитической эксплуатации. Это даст возможность, учитывая заграничный опыт стран ЕС, обеспечить сравнимость агрегированых данных на всех уровнях управления. Внедрение в украинский План бухгалтерских счетов новых счетов для управленческого учета - один из наиболее актуальных путей его развития, а с другой стороны, унификация счетов управленческого учета в масштабах всей страны нуждается в дальнейшей и довольно основательной методологической и методической работе. Научная новизна: заключается в комплексном исследовании Плана счетов бухгалтерского учета и разработке рекомендаций относительно усовершенствования существующего Плана счетов как элемента управления и информационного источника принятия решений. Подходы к построению Плана счетов бухгалтерского учета активов, капитала, обязательств и хозяйственных операций предприятий и организаций Украины в части предложенного содержательного наполнения новым разделом (классом) разрешит усилить информативность данного документа и обеспечить сравнимость данных о результатах хозяйственной деятельности предприятий в современных условиях. Практическая значимость: внесение изменений в действующий План счетов даст возможность бухгалтерам, которые занимаются управленческим учетом и менеджерам повысить эффективность деятельности предприятия.

Ключевые слова: план счетов; управление предприятием; управленческий учет; информация; учет.

\section{UDC 657.4; JEL Classification: M41, D29, M11}

KOVALEVA T. ABOUT IMPROVEMENT CHART OF ACCOUNTS FOR MANAGEMENT GOALS

Purpose of this study is to improve the chart of accounts for the operational management of the enterprise. Methodology of research: to achieve the goal, the following general scientific and special research methods and techniques were used: theoretical generalization, analysis and synthesis; systematic and integrated approach; 
monographic; abstract logical. Findings: the result of scientific work is a theoretical synthesis and development of ways to improve the chart of accounts for the accounting of assets, capital, liabilities and business operations of enterprises and organizations regarding the goals of operational management of an enterprise. Information is an inexhaustible and always relevant resource. The study of the structure of the chart of accounts of Ukraine, in the context of mapping aspects of financial and management accounting in it, give us an opportunity to conclude that it is necessary to approve a decision regarding changes to the existing chart of accounts of our country by including a section (class) of management accounting for the equivalent accounts of analytical exploitation. This will make it possible, taking into account foreign experience of EU countries, to ensure the comparability of aggregated data at all levels of management. The introduction of new management accounts into Ukrainian chart of accounts is one of the most urgent ways to develop it, and on the other hand, the unification of management accounting across the country needs further and rather thorough methodological and methodical work. Originality: lies in a comprehensive study of the chart of accounts and the development of recommendations for improving the existing chart of accounts as a control element and information source of decision-making. Approaches to the construction of the chart of accounts for the accounting of assets, capital, liabilities and business operations of enterprises and organizations of Ukraine in terms of the proposed content filling with a new section (class) will allow to strengthen the information content of this document and ensure comparability of data on the results of business activities of enterprises in modern conditions. Practical value: making changes to the current chart of accounts will enable accountants who are involved in management accounting and managers to improve the efficiency of the enterprise.

Key words: chart of accounts; enterprise management; management accounting; information; accounting

\section{Відомості про авторів / Сведения об авторах / About the Authors}

Ковальова Тетяна Володимирівна - кандидат економічних наук, доцент, Харківський національний автомобільно-дорожній університет, доцент кафедри обліку, оподаткування та міжнародних економічних відносин; м. Харків,Україна; ORCID: https://orcid.org/0000-0003-1250-2019; e-mail: kovaleva64@ukr.net.

Ковалева Татьяна Владимировна - кандидат экономических наук, доцент, Харьковский национальный автомобильно-дорожный университет, доцент кафедры учета, налогообложение и международных экономических отношений.

Kovalova Tetiana Volodimipovna - Candidate of Sciences (Economics), Kharkov National Automobile and Highway University, Associate Professor at the Department of account, taxation and international economic relations, Kharkiv, Ukraine. 